\title{
Finn Bøe - krig, medisin, musikk
}

I januar 1944 plasserte Milorg en radiosender på loftet i Rikshospitalets kvinneklinikk. Med denne sendte Knut Haugland (1917-2009) meldinger til eksilmyndighetene i London. Senderen ble oppdaget av tyskerne, som 1. april 1944 omringet bygningen. Haugland unnslapp under dramatiske omstendigheter.

Mens senderen var i virksomhet, bodde Haugland i tjenesteleiligheten til reservelege Finn Bøe (1906-70), som med fare for sitt eget og familiens liv hjalp i en dramatisk fase av motstandskampen.

Bøe hadde en målrettet klinisk og vitenskapelig utdanning da han i 1943 ble reservelege ved Rikshospitalets kvinneklinikk. Han var faglig ærgjerrig. Hans avhandling fra 1938 ble underkjent, men fire år senere innleverte han et nytt eksperimentelt arbeid til bedømmelse. I 1945 disputerte han. Bøe ble i 1955 den første overlege ved gynekologisk avdeling ved Aker sykehus. Avdelingen ble under hans ledelse den største i Oslo-området og en av de vitenskapelig mest aktive i Norge. Flere av Bøes egne vitenskapelige arbeider om placentamorfologi og karsirkulasjon er blitt klassikere.

Hans store utenommedisinske interesse var musikk, og ikke bare som utøver. Han skrev bok om bysbarnet Edvard Grieg.

Den gamle, ruvende kvinneklinikken i Stensberggata har en verdig fasade i upusset, rød tegl. Ved hoveddøren plasserte Selskabet for Oslo Byes Vel i 1995 et av sine blå kulturhistoriske skilt. Der står det: «Her lå Milorgs radiostasjon Barbette Red» (fig 1).

\section{Bakgrunn, materiale og metode}

Interessen for denne historien - og legen Finn Bøes deltakelse i den - ble vakt da Stiftelsen Nasjonalt medisinsk museum i 2007 inviterte telegrafisten, den nær 90 år gamle Knut Haugland, til Kvinneklinikkens auditorium for å fortelle om hendelsene i 1944 .

Som bakgrunn for artikkelen har vi benyttet databaser som gir tilgang til aviser, bøker og fagmedisinsk stoff (Retriever, bokhylla.no, Bibsys, PubMed, Web of Science) og intervjuet Finn Bøes familie, kolleger og venner samt ekteparet Knut (1917-2009) og Ingeborg Haugland (1921-2014). Vi har hatt tilgang til Knut Hauglands privatarkiv.

Vi har gjennomgått arkivet til Det medisinske fakultet, Universitetet i Oslo, i Riksarkivet for årene 1938-55, med henblikk på behandlingen av de to avhandlingene Bøe sendte inn for vurdering til den medisinske doktorgrad og på professorsøknaden i 1952. I forbindelse med Bøes søknad om et dosentur i 1951 fikk vi hjelp til søk i arkivene ved Universitetet i Bergen og i Kunnskapsdepartementet.

\section{Krig}

«Primus», som står nevnt på plaketten på Kvinneklinikken, var dekknavn for Knut Magne Haugland, telegrafist i Kompani
Linge. Etter tungtvannsaksjonen på Rjukan i februar 1943 dro han i august via Sverige til London. I november var han igjen tilbake i Norge. Han skulle lære opp telegrafister i motstandsbevegelsen og selv sette opp en sender for kontakt med London. Ikke noe av dette var en oppgave for en enkelt mann. Motstandsbevegelsen vektla forsiktighet av sikkerhetsgrunner skulle så få som mulig vite om andres aktiviteter, i tilfelle arrestaaldri til lenge på samme sted. Få visste hvor de lå.

Ideen til dekkadresse for Haugland kom fra motstandslederen Gunnar Sønsteby («Nr 24», «Optimus») (1918-2012) (1). Kontakt med Finn Bøe fikk Sønsteby via byråsjef Finn Haugland (1907-81), aktiv i hjemmefrontens sivile organisasjon. Han anbefalte Bøe som trygg og pålitelig (1). Finn Haugland var aktuar og hadde før krigen hjulpet Bøe med tallbehandlingen $\mathrm{i}$ hans første større vitenskapelige arbeid (2).

Bøes leilighet ble til å begynne med benyttet som dekkleilighet av to studenter som i februar 1943 skulle flykte til Sverige (3), senere i 1943 av Sønsteby selv. Finn Bøe hadde arbeidet på Kvinneklinikken siden 1940 (fig 2). Familien bodde i en tjenesteleilighet i tredje etasje. Det var meningen at Knut Haugland skulle ha opphold der $(1,4)$ og at radiostasjonen skulle ligge et annet sted.

Haugland beskrev selv hvordan møtet med Bøe og hans høygravide hustru Aslaug (1906-98) foregikk (5), og at han raskt gjorde klart for dem faren ved å skjule ham. Bøe hjalp ham med å gjøre seg kjent på Kvinneklinikken. Iført hvit frakk, så han sjon og tortur. Milorgs radiostasjoner holdt

\section{Erlend Hem}

erlend.hem@medisin.uio.no

Klinikk psykisk helse og avhengighet

Oslo universitetssykehus

Jacob B. Natvig

Avdeling for immunologi og transfusjonsmedisin Oslo universitetssykehus

\section{Per E. Børdahl}

Høvik

Engelsk oversettelse på www.tidsskriftet.no

\section{HOVEDBUDSKAP}

Gynekologen Finn Bøe (1906-70) satte sitt eget og familiens liv på spill ved å være en nødvendig hjelper for motstandsbevegelsen under den annen verdenskrig

Finn Bøe ble internasjonalt kjent for sine studier av placenta på samme tid som han bygde opp den gynekologiske avdelingen ved Aker sykehus 


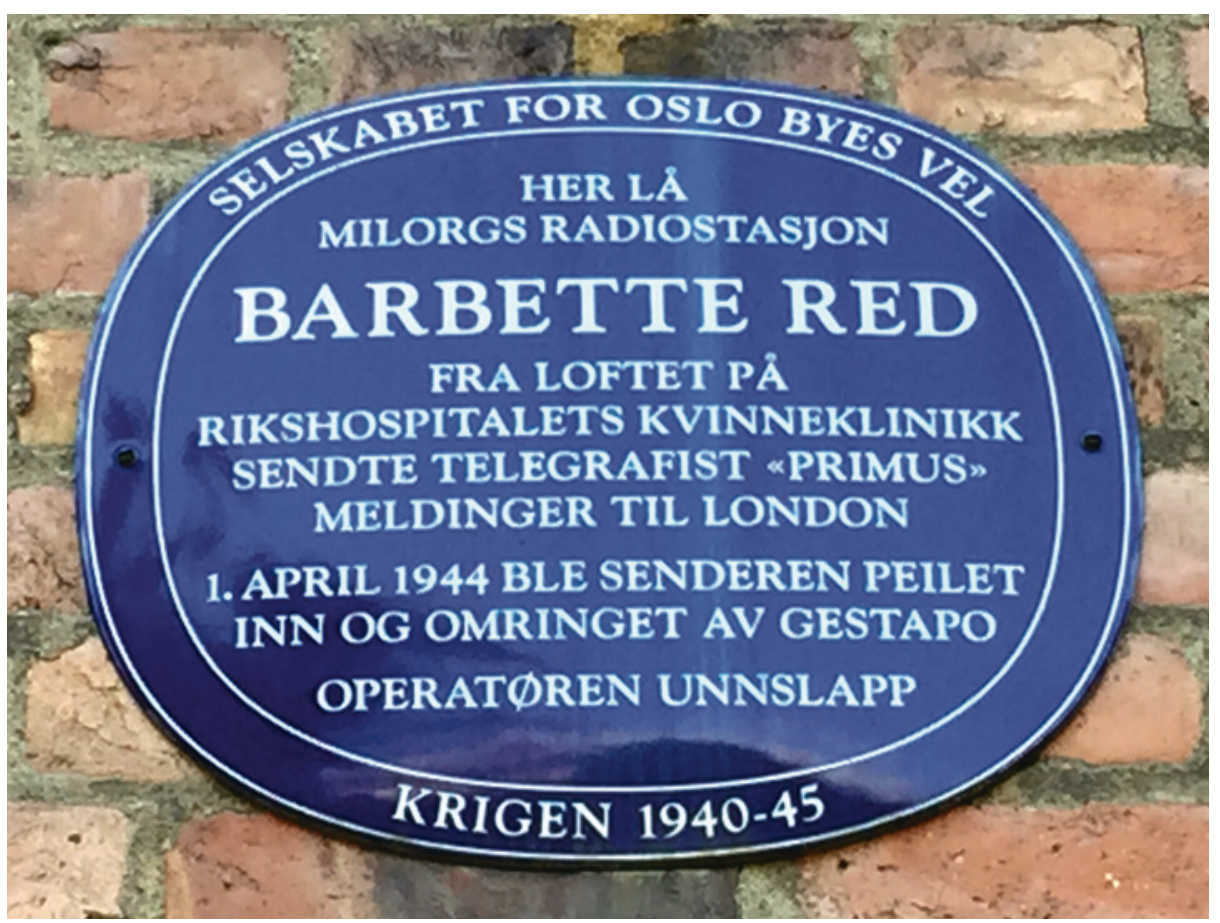

Figur 1 Til venstre for hoveddøren på Rikshospitalets gamle kvinneklinikk står et av de blå kulturhistoriske skiltene til Selskabet for Oslo Byes Vel. Milorgs radiostasjon Barbette Red var plassert på loftet vinteren 1944. Operatøren Knut Haugland klarte å flykte fra den omringede bygningen under dramatiske omstendigheter lørdag 1. april 1944. Foto: Erlend Hem

skulle bli tatt for å være medisinsk kandidat, ble han geleidet gjennom hele bygningen. Det var, med Hauglands ord, «i alt 6 utganger, dessuten var det mulig å hoppe ut av vinduer på alle sider. Stedet var absolutt ideelt for en agent» (5).

Det viste seg upraktisk å følge den opprinnelige planen - bo på Kvinneklinikken hos Bøe og komme seg til og fra senderen. Haugland ville derfor prøve å sende fra loftet på klinikken. Han fant et velegnet, lite «rom» i en sjakt og skrev selv at den «eneste som ble informert var legen, en kar jeg næret en ubetinget tillit til» (5). Han var bekymret for sikkerheten, og fordi sendingene foregikk på lyse dagen, gikk han opp på loftet i skitten overall med en skrunøkkel $i$ hånden. Han ble, kom det senere frem under tyskernes avhør av vaktmesteren, oppfattet som elektriker. Ingen måtte se ham gå ut eller inn av Bøes leilighet (4).

Bøe hjalp ikke bare med dekkleilighet og orientering om bygningen. Han var i starten med på loftet for å sikre at man ikke kunne høre Haugland sende inne fra luftsjakten, og han lærte å kode og dekode telegrammer for å kunne avlaste når det var på det travleste (3). Høsten 1944 forelå det planer om å kidnappe Kriminalrat Siegfried Fehmer (1911-48) og frakte ham til England. Den risikable operasjonen ble det ikke noe av, men Bøe var igjen en mann Sønsteby stolte på (6). funnet, men Bøes fløyleilighet i tredje etasje ble ikke undersøkt. De må, som Haugland skrev, ha regnet med at Kvinneklinikken var stedet for senderen, men at telegrafisten bodde et annet sted. Haugland var etter flukten bekymret for familien Bøes sikkerhet. Han tok raskt kontakt med Bøe og ba ham og familien flykte til Sverige, de skulle få den nødvendige hjelp. Men Bøe syntes det var unødvendig, han mente familien var utenfor mistanke (4).

Det finnes ingen holdepunkter for å tro at andre på Kvinneklinikken kjente til Hauglands opphold på loftet eller hvem den fremmede i Bøes leilighet var. Familien Bøe ble boende i reservelegeleiligheten krigen ut, og den ble oppfattet som en sikker dekkleilighet til tross for begivenhetene i april 1944. Sønsteby bodde der igjen i januar 1945 (1).

Radiosenderen ble altså plassert på loftet i en sykehusbygning der det i 1944 var 2700 fødsler. Situasjonen var ekstrem, og motstandsbevegelsen benyttet sykehus flere ganger. Fehmer skrev om aksjonen på Rikshospitalet at «han ønsket seg den gang at valget av sendersted måtte bero på et tilfelle», men at han «til sin skuffelse» i oktober 1944 oppdaget enda en radiostasjon i et sykehus, denne gang på Radiumhospitalet (8). Også annen motstandsaktivitet skjedde ved Rikshospitalet, blant annet ved Øyeavdelingen, «Bakteriologen» og Rettsmedisinsk institutt $(10,11)$.

Alvorlige etiske problemer er knyttet til det å bruke et sykehusområde, slik Milorg valgte i 1944. Vanskelig sammenliknbare verdier sto mot hverandre - motstandskampen, krigens regler og hensynet til samfunnet. Tidene var ikke normale, og handlinger kan i ettertiden alltid diskuteres.

Bøe var en av dem som satte sitt eget og familiens liv på spill ved å være en nødvendig hjelper i en dramatisk fase av motstandskampen (fig 3).

\section{Medisin}

Finn Bøe ble cand.med. i 1933 og hadde en solid og målrettet utdanning bak seg da han i 1940 ble assistentlege og i 1943 reservelege ved Rikshospitalets kvinneklinikk (12). Tidligere hadde han arbeidet ved Kvinneklinikken i Bergen og Oslo kommunale kvinneklinikk.

Vitenskapelig var han tidlig aktiv, den første artikkelen kom i 1935. Det var endokrinologi og placenta som var hans største interesser, og vitenskapelig er arbeidene om placentasirkulasjon og karmorforlogi de sentrale. Han utfoldet seg også som gynekologisk endokrinolog klinisk, organisatorisk og som redaktør.

Fra 1935 var hans arbeidsplass i to år Farmakologisk institutt, Universitetet 
i Oslo. Dyreeksperimentene som ble utført i 1936-37 var basis for hans første større vitenskapelige arbeid, som han i 1938 leverte til bedømmelse for den medisinske doktorgrad (2). Komiteen fant det «ikke verdig til å forsvares», det ble omtalt som «umodent» (13). Det var den gang sjelden at noen disputerte og enda sjeldnere at de leverte inn et arbeid da de var tidlig i 30 årene.

Men avslaget fratok ikke Bøe motet eller energien, og fire år senere leverte han til bedømmelse et nytt dyreeksperimentelt arbeid om placenta og svangerskapets varighet (14). Grunnet krigen fant ikke forsvaret sted før tre og et halvt år senere, i desember 1945 (14). Avhandlingens tema lå «egentlig utenfor den gynekologiske spesialitet», og ingen av medlemmene i bedømmelseskomiteen var gynekologer (15). Det var det 12. doktorgradsarbeidet av en gynekolog i Norge og det første eksperimentelle (16). Etter endt reservelegetjeneste ved Kvinneklinikken var Bøe fra 1947 ansatt i flere år ved Biologisk laboratorium, Nyegaard \& Co, fra 1950 som sjef.

I 1951 ble det opprettet et dosentur i fødselshjelp og kvinnesykdommer ved Universitetet i Bergen. Finn Bøe var eneste søker. Han ble funnet vitenskapelig kompetent og beskikket som dosent fra september 1951 . Overlege Kristjar Skajaa (1890-1956) ved Oslo kommunale kvinneklinikk, som satt i komiteen, uttalte at Bøe «utvilsomt» var «den gynekolog i landet vårt som er best inne i endokrinologi» (17). Også professor Jørgen Løvset (1896-1981), som var sjef i Bergen, satt i komiteen, og ut fra innstillingen var det tydelig at han ønsket Bøe (17). Bøe skulle lede arbeidet med Hormonlaboratoriet (18). Men lønnsforholdene ble ikke godkjent av Legeforeningen, og Bøe reiste ikke til Bergen (19).

Året etter søkte han professoratet i Oslo da Anton Sunde (1882-1968) gikk av for aldersgrensen. Det fantes den gang bare to professorater i faget, i Oslo og i Bergen. Den andre søkeren var overlegen ved gynekologisk avdeling ved Radiumhospitalet, Ernst Harald Schjøtt-Rivers (1901-82). Uttalelsen fra de sakkyndige er omfangsrik, den fyller 80 sider i universitetets årsberetning (15). Alle innstilte Schjøtt-Rivers som nummer én ut fra soliditeten i og volumet av hans arbeider. Men hvor vanskelig det var å sammenlikne Bøes eksperimentelle arbeider med Schjøtt-Rivers' kliniske ble fremhevet gjennom innstillingen.

Bøe ble berømmet for å ha «angrebet problemer, der er særdeles vanskelige og komplicerede», for sin «ildhu og utrættelige energi» og et «bemærkelsesværdigt talent for experimentel forskning». Løvset påpekte Bøes «affinitet til nye og lite utforskete pro-

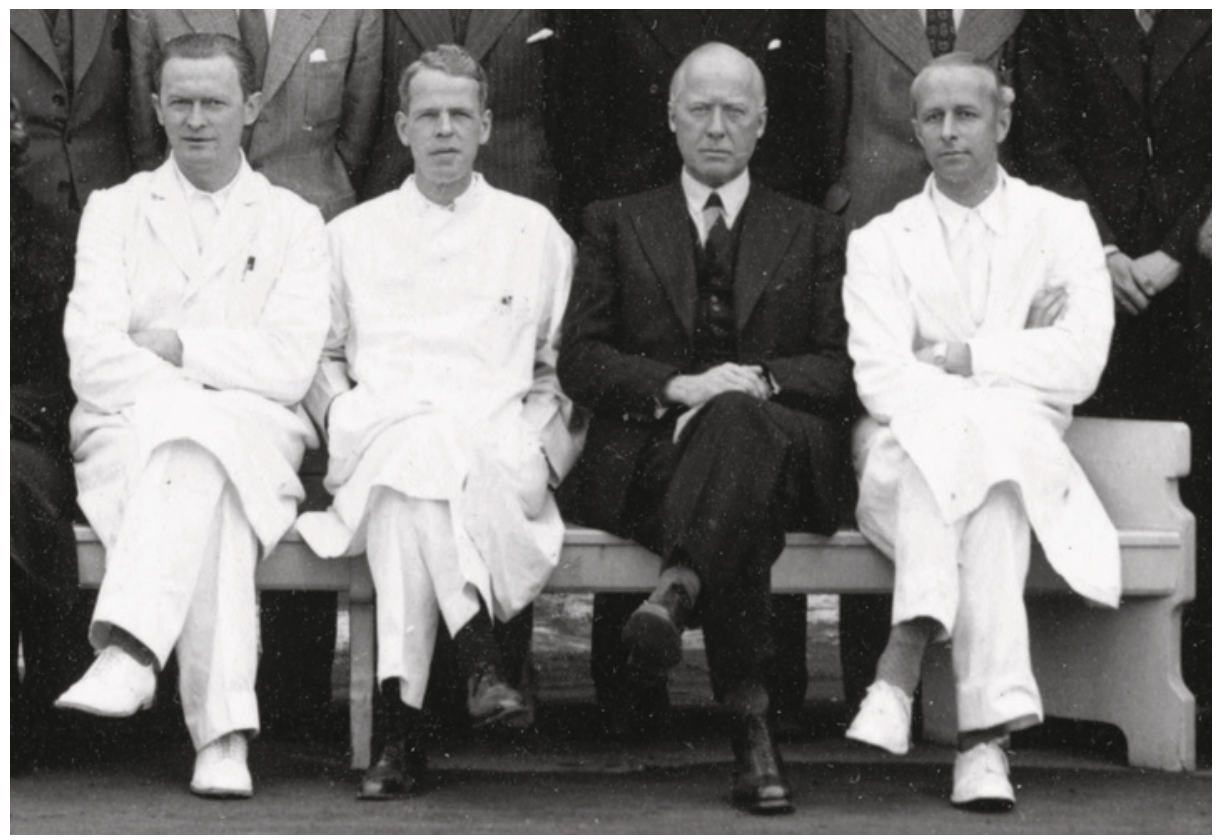

Figur 2 Legestaben utenfor Kvinneklinikken på Rikshospitalet i 1942. Fra venstre assistentlege Finn Bøe (1906-70), reservelege Carl Andreas Hiorth Schultz (1903-87), professor Anton Sunde (1882-1969), reservelege Einar Amundsen (1903-90). Utsnitt. Foto fra Kvinneklinikkens bildesamling, Nasjonalt Medisinsk Museum blemer». Et arbeid som var blitt innsendt etter fristens utløp, og derfor ikke tatt i betraktning, beskrev Skajaa i panegyriske vendinger som «et av de flotteste og verdifulleste arbeider som er gjort i norsk medi$\sin »(15)$. Det var dette arbeidet som senere ga Finn Bøe et internasjonalt navn (20).

Han ble invitert til USA for å legge frem resultatene - ingen dagligdags opplevelse for norske gynekologer i 1950-årene. Ifølge Per Bergsjø (1932-2010) hadde arbeidet «the quality of a classic» (21). En av figu- rene viste det arterio-kapillære-venøse karnett $i$ en tertiær villus ved 18 ukers svangerskap. Den ble reprodusert i tallrike artikler og bøker. I standardverket Pathology of the human placenta vises den skjematiske fremstillingen i alle seks utgavene (1967-2012), og fremdeles refereres det til flere av Bøes arbeider (22).

I 1953 ble Bøe ansatt som gynekologisk konsulent ved Aker sykehus. To år senere ble han den første overlege ved den nyopprettede avdeling samme sted (fig 4). Han

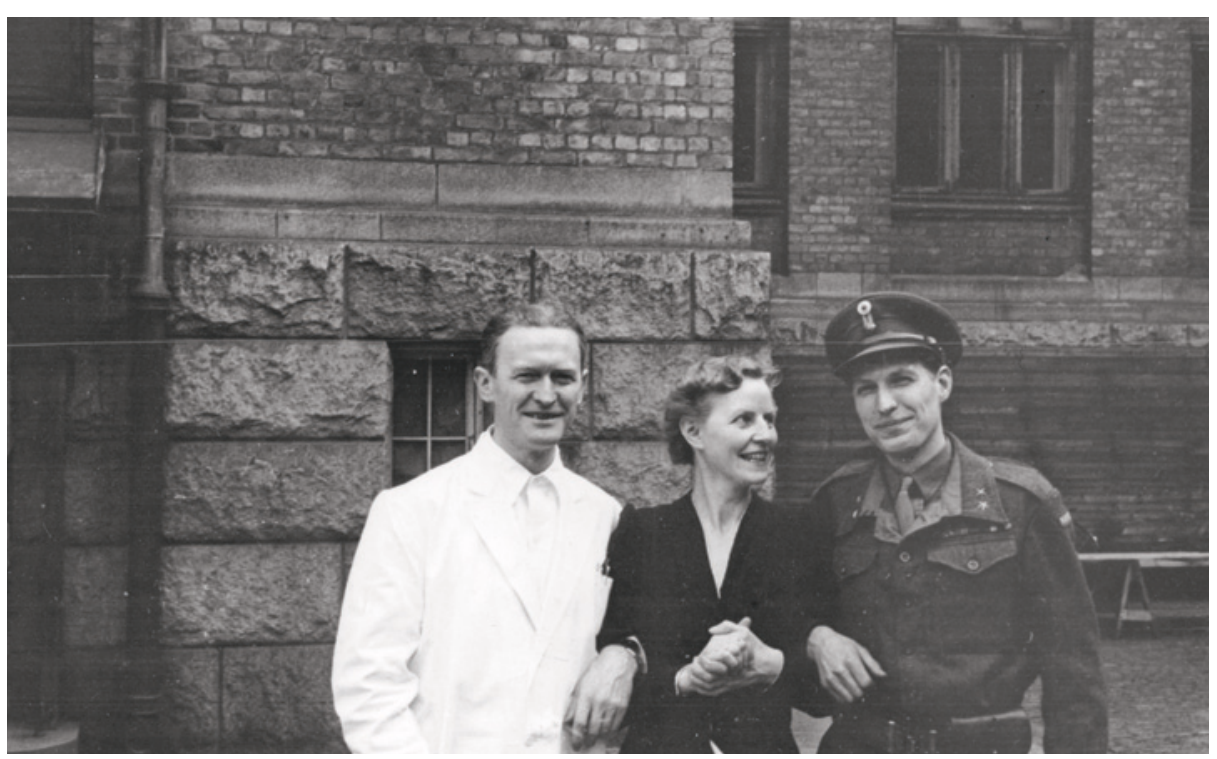

Figur 3 Finn og Aslaug Bøe sammen med Knut Haugland foran Rikshospitalets kvinneklinikk. Årstall ukjent. Foto: Privat 


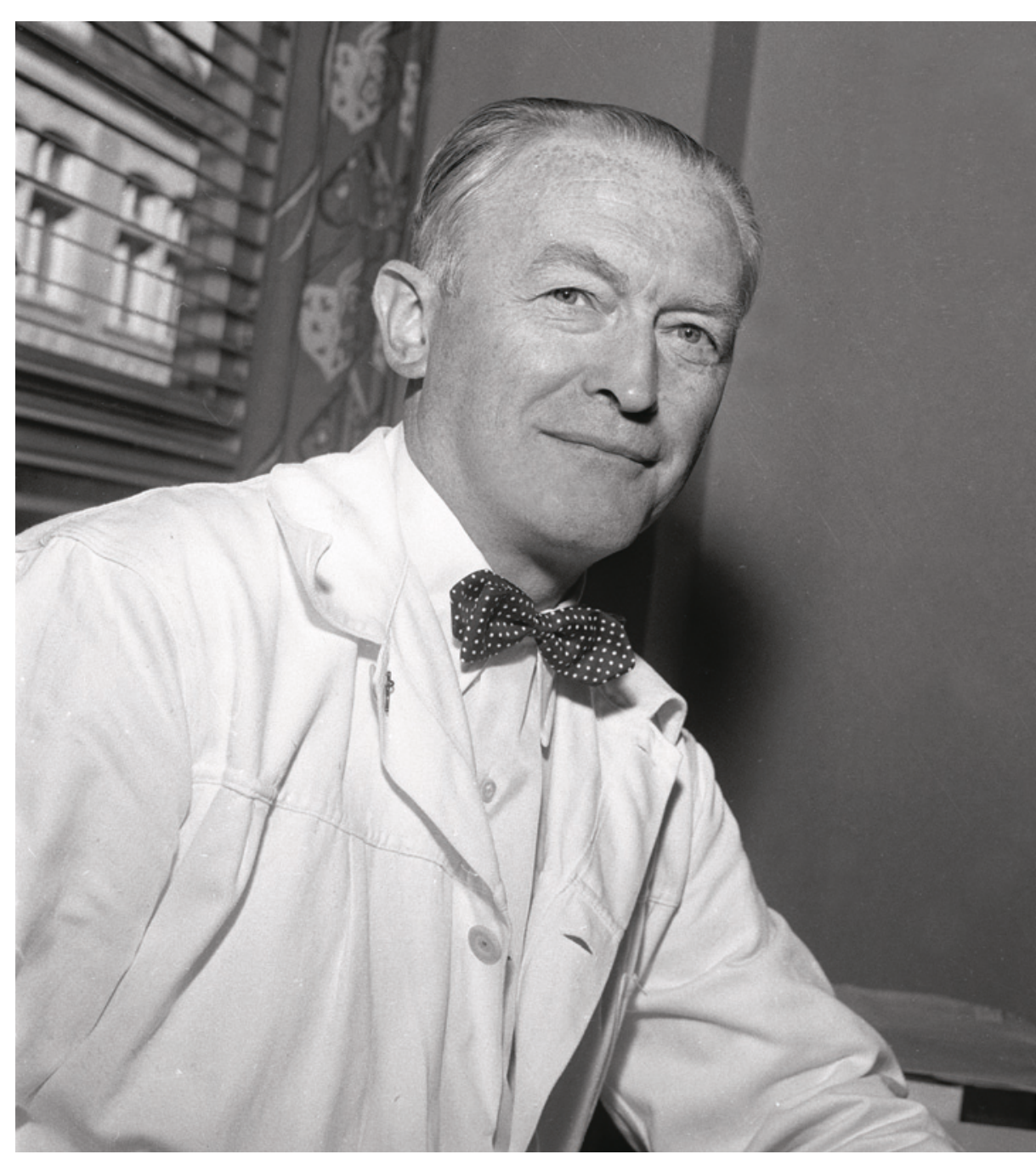

Figur 4 Finn Bøe, nyutnevnt overlege ved den nye gynekologiske avdelingen ved Aker sykehus, fotografert 29. september 1955. Foto: Jan Greve/NTB scanpix

bygde opp avdelingen til å bli den største i sitt slag i Oslo-området og en av de vitenskapelig mest aktive i Norge. Legestaben økte, og han kunne igjen ta opp forskningen sin, som resulterte i flere artikler, den siste i 1969, året før han døde. Også arbeidene fra slutten av 1960-årene inngår fremdeles som referanser i spesiallitteraturen om placenta.

Bøe hadde en rekke faglige verv. Han var formann i Norsk Selskap for Endokrinologi, Oslo Gynekologiske Forening, Norsk Gynekologisk Forening, han var nasjonal redaktør for Acta Endocrinologica og Acta Obstetricia et Gynecologica Scandinavica. Han satte selv særlig pris på presidentskapet for den andre Acta Endocrinologicakongressen i Oslo i $1956(23,24)$. Bøe var opponent for flere sentrale norske gynekologer - Per Agnar Nilsen (1912-2000) i 1963, Knut Bjøro (1925-2010) i 1966 og Narve Moe (f. 1932) i 1970.

Finn Bøe skrev også for et bredere publikum, blant annet i Medisinsk årbok, Fami- lieboka og Nye medisinske fremskritt, han var faglig medarbeider i Gyldendals store konversasjonsleksikon og sto for utgivelsen av den norske versjonen av Kvinnens egen legebok i 1952.

Han og abortnemnda ved Aker sykehus ble et tema i striden om praktiseringen av abortloven fra 1964. Det vakte stor oppsikt at man med samme lov innvilget under halvparten av abortsøknadene ved Oslo kommunale kvinneklinikk og over $90 \%$ ved Aker sykehus (25). Også andre steder i landet ble lovens bokstav tolket ulikt. Dette var en viktig bakgrunn for at man i det politiske miljø innså at noe måtte gjøres med loven. Endringene kom i 1970årene og endte med at kvinnen selv fikk rett til å ta det endelige valget om svangerskapsavbrudd innen 12. svangerskapsuke.

\section{Musikk}

Det er ikke bare et munnhell at leger er opptatt av musikk. Det er dokumentert at de er mer musikalsk aktive, som instrumentalis- ter, sangere og publikum, enn andre akademikere (26).

Finn Bøe var en del av denne tradisjonen. I 1950 ga han en fremstilling av sitt liv de første 25 årene etter artium (27), en av de korteste og mest lakoniske tekstene i en bok der hans studentårskull redegjør for liv og karriere. I Bøes bidrag er det ikke ett ord om krigen, det er en svært summarisk oversikt over det medisinske liv, avsluttet med opplysningen om interesse: «Musikk». Alle som kjente ham, nevner hans store musikalitet, kunnskaper om og interesse for musikk. Ifølge Per Bergsjø var det to temaer som fikk den stillfarne mannen til å tø opp: placenta og Edvard Grieg. I Aftenpostens portrettintervju med ham da han ble 50 år, omtales han i overskriften som «gynekologen og musikeren Finn Bøe» (28).

Bøes interesser gikk utover det å spille selv. I 1949 utga han en monografi om bysbarnet Edvard Grieg (29). Et vitnesbyrd om ham som musiker og hva musikk kan gjøre, kommer til uttrykk i Knut Hauglands nekrolog. Han forteller om det store press han var under da han bodde hos familien Bøe på Kvinneklinikken (30): «(...) vi ble opptatt som fullverdige familiemedlemmer. Det kan ikke vurderes høyt nok hva det betydde i den situasjon vi befant oss i. Motgangen holdt ofte på å ta kvelertaket på oss. Da var det Finn Bøe satte seg til sitt kjære flygel og tryllet frem tonene fra de store mestere og jaget sorgene på dør» (30).

\section{Avslutning}

De som kjente Bøe, nevner alle at han var en fåmælt $\mathrm{og}$ tilbakeholden mann. Han fortalte ikke om sin og konas innsats under krigen. Per Bergsjø, som var assistentlege hos Bøe i tre år i slutten av 1960-årene, skrev at han først langt senere fikk vite om Bøes krigsinnsats (21). Det var ikke noe temaverken i daglig omgang eller i Bøes senere skriftlige oppsummeringer av et levd liv. Det er ikke spor av krigen, verken i hans kortfattede selvbiografi fra 1950 (27) eller i Norges leger (12) - dette i motsetning til hva vi kan lese hos flere andre begge steder. I Finn Bøes få etterlatte papirer finnes det ingenting om krigen, bortsett fra Deltakermedaljen fra 1946. Hans navn ble kort nevnt $\mathrm{i}$ avisene $\mathrm{i}$ forbindelse med Arne Skouens film Omringet (1960), som var basert på hendelsene på Kvinneklinikken i 1944 .

Finn Bøe døde av kreft i 1970, bare 64 år gammel. Ingen uten hans nærmeste visste at han var alvorlig syk (30). «Samme dag som han døde, utførte han en meget besværlig operasjon», het det i Tidsskriftets nekrolog (31).

Kolleger og venner samlet inn penger til en byste av Bøe. Den ble skjenket Aker 
sykehus og avduket i 1978. Den gynekologiske avdelingen ved Aker sykehus ble nedlagt i 2000, men bysten av Bøe står ennå i vestibylen $\mathrm{i}$ bygg 2 .

Vi takker Finn Bøes dattersønn Frédéric Robert Beaujean for verdifulle opplysninger og utlån av bilder.

\section{Erlend Hem (f. 1970)}

er dr.med., fagsjef, styremedlem i Stiftelsen Nasjonalt medisinsk museum og redaktør for Tidsskriftets språkspalte.

Forfatter har fylt ut ICMJE-skjemaet og oppgir ingen interessekonflikter.

\section{Jacob B. Natvig (f. 1934)}

er dr.med., spesialist i immunologi og transfusjonsmedisin, professor emeritus, tidligere Rikshospitalets direktør og styremedlem i Stiftelsen Nasjonalt medisinsk museum. Forfatter har fylt ut ICMJE-skjemaet og oppgir ingen interessekonflikter.

\section{Per E. Børdahl (f. 1944)}

er dr.med., spesialist i fødselshjelp og kvinnesykdommer, pensjonert klinikkoverlege og professor og styremedlem i Stiftelsen Nasjonalt medisinsk museum.

Forfatter har fylt ut ICMJE-skjemaet og oppgir ingen interessekonflikter.

\section{Litteratur}

1. Sønsteby G. Rapport fra «Nr. 24». Oslo: Orion, 1996: 84, 110-5, 179, 193. www.nb.no/nbsok/nb/ 3502 c44c13a92984986a445c75a57d58?index $=5 \# 0$ (3.7.2015)

2. Bøe F. Studies on prolonged pregnancy in rats. Acta Pathol Microbiol Scand Suppl 1938; 36: 1-146.

3. Haugland K. Søknad om Deltakermedaljen for Aslaug og Finn Bøe. Udatert dokument. Knut Hauglands privatarkiv.

4. Sæter S, Haugland KM. Operatøren: Knut Hauglands egen beretning. Oslo: Cappelen Damm, 2008: $130-50$
5. Haugland K. Rikshospitalets kvinneklinikk. Stasjonsplass for Curlew. Udatert dokument. Knut Hauglands privatarkiv.

6. Kraglund I, Moland A. Hjemmefront. Bd. 6. I: Skodvin $M$, red. Norge i krig: fremmedåk og frihetskamp 1940-1945. Oslo: Aschehoug, 1987: 262. www.nb.no/nbsok/nb/674ef16c660a26942c17259 778168 b8a.nbdigital?lang=no\#265 (3.7.2015).

7. Jensen E, Ratvik P, Ulstein R. Kompani Linge. Bd. 2. Oslo: Gyldendal, 1948: 364-8. www.nb.no/ nbsok/nb/3bd848eb1c1256f3f69e9d9c12b27561. nbdigital? lang=no\#365 (3.7.2015)

8. Fehmer SW. Meine Tätigkeit bei der geheimen Staatspolizei: Erlebnisse, Erfahrungen, Erkenntnisse. Utrykt manuskript. Nasjonalbiblioteket i Oslo, 1946: 164-6.

9. Niølstad O. Jens Chr. Hauge - fullt og helt. Oslo: Aschehoug, 2008: 181-2, 761.

10. Elster T. Rikets hospital: historien om et lite samfunn i den store verden. Oslo: Aschehoug. 1990.

238-42. www.nb.no/nbsok/nb/15970bd30ee0ac5d $12 \mathrm{~d} 88 \mathrm{abf3ae} 145 \mathrm{db}$.nbdigital? lang=no\#241 (3.7.2015).

11. Øyen O. Milorg D13 i kamp: episoder fra det hemmelige militære motstandsarbeidet i Oslo og omegn under okkupasjonen nedtegnet etter Milorgrapporter og personlige beretninger. Oslo: Nova, 2011: 58-61.

12. Larsen $\emptyset$, red. Norges leger. Bd. 1. Oslo: Den norske lægeforening, 1996: 538. www.nb.no/ nbsok/nb/7792a2ae04bb8081194fabd36b5c73eb. nbdigital?lang=no\#541 (3.7.2015)

13. Uttalelse fra sakkyndig komité Einar Langfeldt, Georg Waaler og Anton Sunde 3.12.1938. Sakarkiv. Journalsaker. Det medisinske fakultet, Universitetet i Oslo 1938-I, Boks 63: Doktorgrader 1938 Riksarkivet RA/S-2536/1/D/Da/L0063. http://arkivportalen.no/side/arkiv/detaljer?arkivld= no-a1450-01000000432178 (1.9.2015).

14. Bøe F. The placenta in experimental interruption and prolongation of pregnancy: histological and metabolism investigations in rats. Acta Obstet Gynecol Scand Suppl 1942; 22 (Suppl 2): 1-167 www.nb.no/nbsok/nb/c00f3a08383c0643de297e 728a87c18b.nbdigital?lang=no\#0 (3.7.2015).

15. Årsberetning 1. juli 1952-30. juni 1953. Utgitt av universitetssekretæren. Universitetet i Oslo. Oslo: Universitetsforlaget, 1956: 63-143.

16. BørdahL PE. Vitenskapelige bidrag. Gynekologenes doktorgrader. I: Børdahl PE, Jerve F, Moen MH, red. Midt i livet. Norsk gynekologisk forening 1946-1996. Trondheim: Tapir, 1996: 289-97.

17. Dosentur i fødselshjelp og kvinnesykdommer. Tilsettinger i vitenskapelige stillinger. Årsmelding 1951 -52, Universitetet i Bergen. Bergen: John Griegs boktrykkeri, 1952: 167.

18. Tilsettingsbrev 29.9.1951. J.nr. 283/N/51. Arkivet, Det medisinske fakultet, Universitetet i Bergen.

19. Innstilling. Jnr. 4352 D 52, datert 3.9.1954. Arkiv:
Kirke- og undervisningsdepartementet, Kulturavdelingen RA/S-2309/D/Db/L0233/0005. Serie: Sakarkiv ordnet etter arkivnøkkel II. Stykke 211.1: Tilsetting og avskjed. Universitetet i Bergen. Dosenturer. Ymse stillinger. Mappe: Det medisinske fakultet 1951-58. Oppbevares i Kunnskapsdepartementets arkiv. http: //arkivportalen.no/ side/arkiv/detaljer?arkivld=no-a1450-0100000058 7050 (1.9.2015)

20. Bøe F. Studies on the vascularization of the human placenta. Acta Obstet Gynecol Scand Suppl 1953. 22 (Suppl 5): 1 -91. www.nb.no/nbsok/nb/ $141076 f 81 b 2843431335 f 05 a 81405 d 84$ nbdigital? lang=no\#0 (3.7.2015)

21. Bergsjø P. Acta fifty years ago. Description of an ovarian pregnancy, and a tribute to its author. Acta Obstet Gynecol Scand 1992: 71: 3-5

22. Benirschke K, Burton GJ, Baergen R. Pathology of the human placenta. 6. utg. New York: Springer 2012: 5, 113-5, 202, 525

23. Transactions of the second Acta Endocrinologica Congress: held at Fysisk institutt, Oslo, Norway August 12th to 15th, 1956. Acta Endocrinol Suppl (Copenh) 1957; 31: 1-333.

24. Vogt JH. Finn Boe, on the occasion of his sixtieth birthday. Acta Endocrinol (Copenh) 1966: 52: 1-2.

25. Bergsjø P. Erindringer om Finn Bøe. Gynekologen tidsskrift for Norsk gynekologisk forening 2008: nr. 4: 8-9. http: //legeforeningen.no/PageFiles/ 4578/Gynekologen\%204-2008.pdf (3.7.2015).

26. Nylenna M, Aasland OG. Kulturell og musikalsk aktivitet blant norske leger. Tidsskr Nor Legeforen 2013; 133: 1307-10

27. Møller TJ. red. Studentene fra 1925: biografiske opplysninger og statistikk samlet til 25-års jubileet 1950. Oslo: Oskar Andersens boktrykkeri, 1950: 51 www.nb.no/nbsok/nb/88ae98ff68350f226ef19a28cd 4640b1.nbdigital?lang=no\#100 (3.7.2015).

28. A.F. Økende antall overtidige svangre gjennom det siste halve århundre. Aftenposten morgen 30.5.1956: 5.

29. Bøe F. Trekk av Edvard Griegs personlighet. Oslo: Johan Grundt Tanum, 1949. www.nb.no/nbsok/nb/ 391b6b52b9aa0d18e2bea37ed74c55f7.nbdigital? lang=no\#0 (3.7.2015)

30. Haugland K. Overlege Finn Bøe død. Aftenposten morgen 4.11.1970: 20

31. C.S. [Carl Schultz]. Finn Bøe In memoriam. Tidsskr Nor Lægeforen 1970; 90: 2209.

Mottatt 1.9. 2015, første revisjon innsendt 14.12. 2015, godkjent 10.2. 2016. En av forfatterne er redaktør i Tidsskriftet. Manuskriptet er derfor behandlet eksternt av setteredaktør Magne Nylenna. 